\title{
Measuring the relationship among Digital Marketing Expenditure and Profit of women luxury clothing Brands in Pakistan
}

\author{
Dr. Sadaf Mustafa ${ }^{1}$ \\ Assistant Professor, Department of Commerce, \\ University of Karachi, Pakistan \\ Ayesha Fareed ${ }^{2}$ \\ Lecturer, Department of Commerce \\ University of Karachi, Pakistan \\ Faryal $\mathrm{Ikram}^{3}$ \\ M.Phil. Scholar, Department of Commerce, \\ University of Karachi, Pakistan
}

\begin{abstract}
The buying behavior of customers are changing faster than the customer oriented market environment. Every customer has unique buying behavior, which differs when it comes to the 4p's (product, price, place and promotion). However, Women are the most complicated group to judge with their buying behavior, because they mostly follow the changing trends of fashion and taste. Therefore, Marketers are spending more money on market research every year to identify and forecast the changing behavior of women. Now in the retail segment digital marketing posed many challenges for marketers. The young women can easily have attracted through online shopping than the traditional buying through shops. The marketers are enforced to find out new way of selling product due to the pressure of changing women's buying behavior. The aim of this research paper is to investigate the relationship among Digital Marketing expenditure \& sales revenue. We have selected 9 women clothing brands. We found that there is linear and significant relationship among all the variables of Digital Marketing expenditure profit. It represents a direct relation, if increasing Digital Marketing expenditure, it leads to increasing sales and profit will also increase. It is also noted in trend analysis that increased Digital Marketing expense next year leads to generate more sales revenue and profit.
\end{abstract}

Key Words: Digital Marketing, Promotions, Traditional Marketing

DOI: $10.7176 / \mathrm{JMCR} / 54-09$

Publication date:March $31^{\text {st }} 2019$

\section{Introduction}

Buying \& selling of product and services through internet or via mobile \& computer network is Digital Marketing. Internet \& E- Commerce had entirely changed the concept of economy, Business models, revenue, customer's perceptions \& retail branding. According (Damian Rayan \& Calvin Jones, 2009), digital marketing has not been able to get a comprehensive and exact definition by the scholars. Now a days digital marketing has become a broad field. Different scholars have different definition of digital marketing, but have failed to present one particular definition like definitions of traditional marketing presented forth in the past (Damian Rayan \& Calvin Jones, 2009). However, (Tehrani Nik, 2009)believed that digital marketing should present as a new phenomenon whereby marketers engage in quick and rapid communication with their customers by the means of all new communication methods and channels. Today digital marketing has become a broad communication channel, it can be change easily according to consumer needs and tastes. Companies make specific marketing campaign designed for a targeted audience, (Tehrani Nik, 2009).

According to (Ghauri \& Cateora, 2014) digital marketing is a two-way interaction platform between consumers and the marketers. Digital marketing is a latest communication tool for marketing campaign of a company by engaging in an interactive and meaningful communication with the customer (Ghauri \& Cateora, 2014). The new global technology is the bottom-line of digital marketing that not only allows a smooth communication between the seller and buyer but also provide a media for the communication. (Ghauri \& Cateora, 2014). Women Customers of online shopping have become more satisfy and delighted with quick delivery and easy payment, because it saves their time and traveling expense. Retailors are now targeting women more than men by using intangible assets such as contacts, information, individuals, brands, and systems. 
Review of Literature

(Damian Rayan \& Calvin Jones, 2009); A great deal of research has been conducted on the point whether women are more likely to buy luxury products than men .This traditional area of research gained another dimension because of the overarching influence of digital means of communications on women Researchers argue that women are more inclined to buy luxury goods than the male population because of the prevalence of hedonic motives Marketers give a special emphasis towards their female target audience to persuade them positively.

(Damian Rayan \& Calvin Jones, 2009). women are more up-to-date with the latest trends and fads. The clothing retailers exploit this tendency and ensure that their products are always relevant in the market. For the purpose, fads are created and propelled by these clothing brands to ensure that customers are forced to buy a certain type of product in greater volumes. In addition to this, fashion industry has become a field with their special journals. These journalists provide information to the consumers regarding the latest fashion trends, in vogue ideas and clothing options. Women consume these journalistic articles more than men and thus a need is created for them to buy such products. Likewise, these fashion journalists also give information to the consumers regarding the brand value, bargain options, sales, offers, brand value and so forth. Women are also more interested in such offers and keep them abreast and avail them more than men.

(Vishal Khasgiwala \& Monica Sainy ,2011); says in their study that gender buying behavior still need more study, impulsive buying behavior should also have experimented. Impulsive buying is very common behavior today and need no setting to occur. Impulse are naturally stimulated, after any human activity. Impulse buying creates natural desire to immediate purchases, without any planned shopping to fulfill a specific need. It's an unconscious activity connected with certain stimulus. Digital marketing brings a boom in economy by creating online shopping channels, and Internet expands consumers' impulse purchasing opportunities by $24 / 7$ delivery. Impulse buying is an unplanned purchase stimulation converted to quick buying decision.

(Dastidar \& Datta, 2009). Says that impulsive buying behavior in women are greater than men. It explains that young female has risk/innovation, and curiosity motivated behavior.

They suggest marketers to focus more on great population of country, young ladies in India.

(Sathish and A. Rajamohan, 2012). In their study they describe Consumer behavior as psychographic interaction with environment. Buying behavior is integrated with human's attitudes, values, interests, opinions and his over behavior. It is found that "Consumer behavior is still need more studies and research

(Cengel, F. Y., 2012). Online Academic Journal of Information Technology. in his article mentions that marketer like to target youth, below 35 years of age. Because young ones are more ambitious, technology-oriented and confident.

(Holmberg and Öhnfeldt,2010);A great deal of research has been conducted on the point whether women are more likely to buy luxury products than men .This traditional area of research gained another dimension because of the overarching influence of digital means of communications on women Researchers argue that women are more inclined to buy luxury goods than the male population because of the prevalence of hedonic motives Marketers give a special emphasis towards their female target audience to persuade them positively.

(Rovai, 2015). Women are more up-to-date with the latest trends and fads. The clothing retailers exploit this tendency and ensure that their products are always relevant in the market. For the purpose, fads are created and propelled by these clothing brands to ensure that customers are forced to buy a certain type of product in greater volumes. In addition to this, fashion industry has become a field with their special journals. These journalists provide information to the consumers regarding the latest fashion trends, in vogue ideas and clothing options. Women consume these journalistic articles more than men and thus a need is created for them to buy such products. Likewise, these fashion journalists also give information to the consumers regarding the brand value, bargain options, sales, offers, brand value and so forth. Women are also more interested in such offers and keep them abreast and avail them more than men.

\section{Digital Marketing Scenario in Pakistan}

The existing research is particular the role of gender in individual's purchase decisions and the impact of modern digital marketing channels on women buying decision in Pakistan. This area was negligible and need research studies. Since, the existing studies are not conclusive and need more work regarding booming internet marketing industry in Pakistan. In Pakistan social media is the adopting all new strategies to improve digital marketing. The retail sector in Pakistan is successful growing both on and offline. Mostly Pakistani women are more conscious about branded products. The desire of women can be satisfied to their consumption of luxury items and they perceive that somehow gives them an air of positivity and happiness ( Hareem Zeb, Kashif Rashid, and M.Bilal Javeed, 2011). Therefore, in order to experience more positive feedbacks from women it was observed women spend more luxury than the men ( Hareem Zeb, Kashif Rashid, and M.Bilal Javeed, 2011). In addition to this, women also buy expensive products without giving too much thought to the utility of the purchase but due to their sudden need or makeup to do so ( Hareem Zeb, Kashif Rashid, and M.Bilal Javeed, 2011). Thus, marketers 
specially target female audience and influence them positively. The study will be useful for the marketer to use new marketing strategies to capture the present women segment in the luxury brand products.

\section{Relationship between Marketing Expenditure and Sales Revenue:}

Digital Marketing is a paid form of promotion of goods \& services, Marketing is used to provide basic information about product, additionally it's also promote benefits of product. Profit is the amount gets from revenue minus expenditure. Marketing does inform public about the product but also preference to like it (Figen Yildrim \& Özgür Çengel, 2012). Sales Revenue is amount company will get from total sales than deduct all expenditure and come at profit figure. It has a positive relation when sales integrated with Marketing. It is a better way of communication.

In many studies relationship between Marketing expense with profitability have already examined. (Gbolagade, A, Adesola, M A, Oyewale, 2013) concluded a positive relationship between marketing expense and total sales in their study. They also found negative relationship between TV advertisement and total sales. As per (Oloko, M, Anene E B, Kiara P G, Kathambi I, Mutulu J, 2014) European advertisers reinvest 3 percent more on marketing expense to capture more revenue by retention of customers \& loyalty programs. (Kingdom of Saudi Arabia, 2013) (Halaoui H, Smayra C, Sursock L, Booz and Company, 2011) found a positive relationship between marketing practices \& profitability with customer loyalty of Saudi Telecom Company. They also found that marketing expense play a significant key role in determining profitability in market.

\section{Need for study}

There is many research already have worked on establishing relationships between marketing expense \& profitability. There is a gap of research work bringing out relationship of Digital Marketing Expenses with Profitability. However, if a company would like to know the effectiveness Digital marketing expenses on profitability, a research should be conducted. This research might be helpful in importance to the management of women luxury clothing brands for making some important decisions that in future if they want to increase the profitability of their firms, they should focus on Digital Marketing.

\section{Research Hypothesis;}

Ho: There is positive correlated between Digital Marketing Expenditure and profit.

H1: There is no positive correlated between Digital Marketing Expenditure and profit.

\section{Research Methodology:}

This research paper is based on secondary data collected from 9 women luxury clothing brands in Pakistan. The data was based on annual publish research report and follows the research procedure. After examining researcher found the relationship among Digital Marketing expenditure and net profit by taking yearly profits, sales revenue and Digital Expenditure The name of the companies are as follows:

\begin{tabular}{|l|l|}
\hline Name of the company & Financial year \\
\hline Gul Ahmed & $2012-2018$ \\
\hline Nish at Linen & $2012-2018$ \\
\hline Al Karam & $2012-2018$ \\
\hline Bonanza & $2012-2018$ \\
\hline Sana \& Safinaz & $2012-2018$ \\
\hline Sapphire & $2012-2018$ \\
\hline Khaddi & $2012-2018$ \\
\hline Eden robe & $2012-2018$ \\
\hline Ethnic & $2012-2018$ \\
\hline
\end{tabular}

Test of Research Hypothesis

The relationship between the two variables is described as simple regression model. 
Simple Liner Regression model for $\mathrm{Y}$ on $\mathrm{X}$ is given by:

$\mathrm{Yi}=\beta 0+\beta 1 \mathrm{Xi}+\varepsilon \mathrm{i}(\mathrm{i}=1, \ldots ., 70)$

Where, $Y=$ Dependent Variable (Profit),

$\mathrm{X}=$ Independent variable (Digital Marketing Expenditure),

$\beta 0=$ Intercept,

$\beta 1=$ Slope and

$\varepsilon=$ Random Error.

Regression Analysis: To analysis this equation Regression model is used, with a value of 0.05 (level of significance) that corresponds to a 95\% confidence level. All tables presented in below as output from MS Excel.

Model Summary ANOVA

\begin{tabular}{|l|l|l|l|l|l|}
\hline Model & Sum of square & df & Mean Square & f & Significance \\
\hline Regression & 30832451320283050000 & 1 & 30832451320283050000 & 97.466 & .000 \\
\hline
\end{tabular}

Dependent Variable; Profit

Constant; Digital Marketing Expense

Coefficients

\begin{tabular}{|l|l|l|l|l|l|}
\hline Model & \multicolumn{2}{|l|}{ Un Standardized Coefficient } & $\begin{array}{l}\text { Standardized } \\
\text { coefficient }\end{array}$ & $\mathrm{t}$ & Significance \\
\hline & $\mathrm{B}$ & Std. Error & Beta & & \\
\hline Constant & 550772729.274 & 86954767.997 & & 6.334 & .000 \\
\hline $\begin{array}{l}\text { Digital } \\
\text { Marketing } \\
\text { Expenditure }\end{array}$ & 6.502 & .659 & .767 & 9.872 & .000 \\
\hline
\end{tabular}

\section{Dependent Variable; Profit}

\section{Discussion}

The results of the model Regression analysis show that at the 5\% level of significance, the coefficients of the intercept and Digital Marketing Expenditure are statistically significant. Additionally, the analysis of the TStatistics (T-TEST) is the coefficient \& divided by its standard error which is estimated of standard deviation of the coefficient. This model is statistically significant \& give the Calculated F-value is 97.466 which is greater than Table F-value $2.82 \&$ level of significance.

$\mathrm{P}$ - value $000 \%$ is less than $\mathrm{P}$ value $0.05 \%$. Which shows our proposed model is statistically significant. The model also found that from the regression analysis, calculated t-value is 9.872 which is greater than table $t$ value $2.00 \&$ level of significance $\mathrm{P}$ value is $0.000 \%$ which is less than $\mathrm{P}$ value $0.05 \%$. It shows that null hypothesis is accepted. So, this research give result that shows that Digital Marketing expenditure and Profit are positively correlated. It shows that use of greater marketing communication tools as digital Marketing advertisement to increase yearly Profit. 


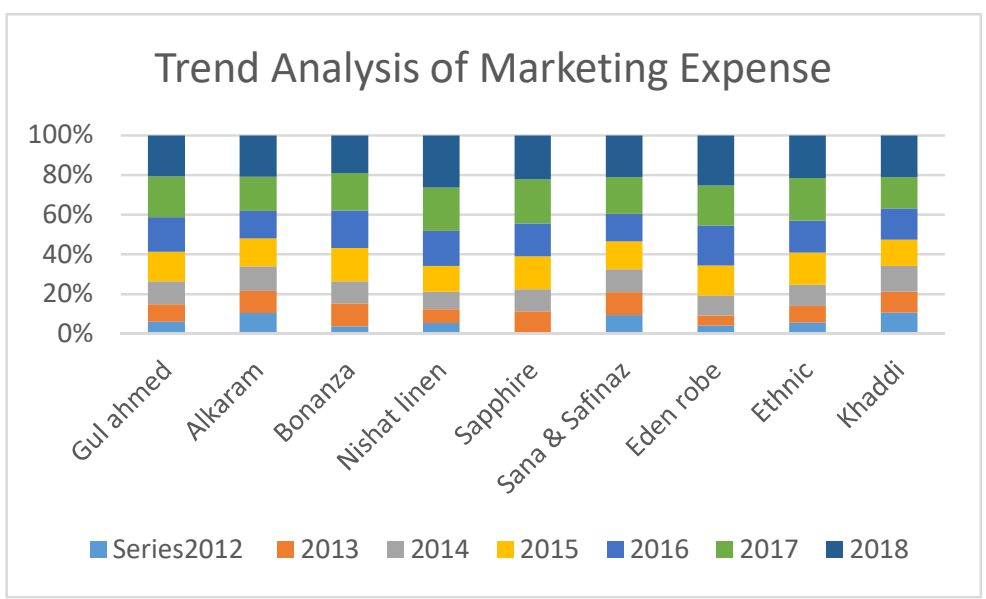

\section{Conclusions}

This paper shows that there is significant positive relation among Digital Marketing Expenditure \& profit. It also shows a trend analysis by increasing marketing expense sales revenue increases which leads to increase in profit. Spending more money on advertisement result more profit. The world has become a global village digital marketing are playing a significant role about awareness of products, and bringing people closer day by day.

\section{References}

Hareem Zeb, Kashif Rashid, and M.Bilal Javeed. (2011). Influence of Brands on Female Consume's Buying Behavior in Pakistan. International Journal of Trade, Economics and Finance, Vol. 2, No.3,

Damian Rayan \& Calvin Jones. (2009). Understanding Digital Marketing marketing strategies for engaging the digital generation. United States Of America.

Figen Yildrim \& Özgür Çengel. (2012). The Perceived Risk and Value Based Model of Digital Marketing. Online Academic Journal of Information Technology.

Gbolagade, A, Adesola, M A, Oyewale. (2013). 'Impact of marketing strategy on business performance A study of selected small and medium enterprises (SME) in Oluyole local government, Ibadan, Nigeria. IOSR Journal of Business and Management.

Ghauri \& Cateora. (2014). International Marketing, . McGraw-Hill Education, Maidenhead, Berkshire. 4th Edition.

Halaoui H, Smayra C, Sursock L, Booz and Company . (2011). Avoiding the Slippery Slope How GCC Telecom Operators Can Improve Profitability. http://www.strategyand.pwc.com/media/uploads/StrategyandGCCTelecoms-Improve-Profitablity.pdf, dated accessed 20 Feb 2015. .

Oloko, M, Anene E B, Kiara P G, Kathambi I, Mutulu J. (2014). Marketing Strategies for Profitability: A Case of Safaricom Ltd in Kenya Telecommunication Industry. International Journal of Scientific and Research publication.

TeAaker, D. A. (1991). Managing brand equity. The free press newyork.

Cengel, F. Y. (2012). The Perceived Risk and Value Based Model of Digital Marketing. Online Academic Journal of Information Technology.

Dastidar, S.G. and Datta, B. (2009). Demographic differences in consumer exploratory tendencies:. IIMB Management Review, Vol. 21,.

Ghauri \& Cateora. (2014). International Marketing, . McGraw-Hill Education, Maidenhead, Berkshire. 4th Edition. 
Holmberg, J., \& Öhnfeldt, R. (2010). . The female fashion consumer behaviour: from the perspective of the shop Fever in Gothenburg. Bachelor Thesis, Gothenburg. Sweden.

Reichheld, F.F., \& Sasser, W.E. Jr. (1990). Zero defects comes to services. Harvard Business Review,.

Rovai, A.P. (2015). Building sense of community at a distance. The International Review of Research in Open and Distributed Learning.

Ryan D \& Jones C. (2009). Understanding Digital Marketing marketing strategies for engaging the digital generation. London and Philadelphia, Kogan.

Sathish, S. and Rajmohan, A. (2012). Consumer Behavior \& Lifestyle Marketing. International Journal of Marketing, Financial Services \& Management Research.

Tehrani Nik. (2009). Contemporary marketing mix for the digital era. 2nd Edition. USA. Author House.

Vishal khasgiwala \& Monica sainy. (2014). Factors Influencing Consumer Buying Behavior towards Bikes among Indhrani Nik. (2009). Contemporary marketing mix for the digital era. 2nd Edition. USA. Author House. 